\title{
CPTP wt Allele
}

National Cancer Institute

\section{Source}

National Cancer Institute. CPTP wt Allele. NCI Thesaurus. Code C113111.

Human CPTP wild-type allele is located in the vicinity of $1 p 36.33$ and is approximately $4 \mathrm{~kb}$ in length. This allele, which encodes ceramide-1-phosphate transfer protein, plays a role in glycolipid transport. 